University of Nebraska - Lincoln

DigitalCommons@University of Nebraska - Lincoln

Faculty Publications in Food Science and Technology

Food Science and Technology Department

2003

\title{
Wheat Tortilla Quality: Impact of Amylose Content Adjustments Using Waxy Wheat Flour
}

G. Guo

University of Nebraska-Lincoln

David S. Jackson

University of Nebraska-Lincoln, djackson1@unl.edu

Robert A. Graybosch

University of Nebraska-Lincoln, bob.graybosch@ars.usda.gov

Anne M. Parkhurst

University of Nebraska-Lincoln, aparkhurst@unl.edu

Follow this and additional works at: https://digitalcommons.unl.edu/foodsciefacpub

Part of the Food Science Commons

Guo, G.; Jackson, David S.; Graybosch, Robert A.; and Parkhurst, Anne M., "Wheat Tortilla Quality: Impact of Amylose Content Adjustments Using Waxy Wheat Flour" (2003). Faculty Publications in Food Science and Technology. 99.

https://digitalcommons.unl.edu/foodsciefacpub/99

This Article is brought to you for free and open access by the Food Science and Technology Department at DigitalCommons@University of Nebraska - Lincoln. It has been accepted for inclusion in Faculty Publications in Food Science and Technology by an authorized administrator of DigitalCommons@University of Nebraska - Lincoln. 


\title{
Wheat Tortilla Quality: Impact of Amylose Content Adjustments Using Waxy Wheat Flour ${ }^{1}$
}

\author{
G. Guo, ${ }^{2}$ D. S. Jackson, ${ }^{2.3}$ R. A. Graybosch, ${ }^{4}$ and A. M. Parkhurst ${ }^{5}$
}

\section{ABSTRACT}

Amylose content is closely related to wheat flour pasting or thermal properties, and thus affects final food qualities. Fourteen flour blends with amylose content ranges of $<1$ to $29 \%$ were used to study tortilla production and quality parametcrs. Reduced amylose contents decreased dough stickiness and pliability; low amylose doughs werc also very smooth in appearance. Very low flour amylose content was associated with earlier tortilla puffing and poor machinability during baking, darker color, low opacity, larger diameters, and reduced flexibility after storage. Tortilla texture analysis indicated that lowering amylose content gave fresh tortillas higher extensibility; after three or more days storage, however, low amylose flours requircd more force to break the tortillas and the rupture distances became shorter. These results, as reflected in covariate analysis, were not significantly aflected by the flour blend's protein content, swelling volume/power, SDS-sedimentation volume, mixograph dough devclopment time, or mixograph tolerance score. Based on our observation of an initial increase in extensibility with reduced-amylose tortillas, adding 10-20\% waxy flour into wild-type flours should be ideal for restaurant (on-site) tortilla production or circumstances where tortillas are consumed shortly (within a day) after production. The optimal flour amylose content for hot-press wheat tortilla products is $24-26 \%$.
Tortillas are unfermented flat breads or pancakes made from either corn or wheat. As the staple bakery food, tortilla products have been traditionally homemade and widely consumed in Mexico for centuries (Serna-Saldivar et al 1988; Wang and Flores 1999a). In the United States, tortillas, especially wheat tortillas, are more popular today than all other ethnic breads (Dally and Navarro 1999). According to the Tortilla Industry Association (TIA), tortilla sales for 2000 in the U.S. reached the $\$ 4.4$ billion mark and are expected to hit $\$ 5.7$ billion dollars in sales by the year 2002 (Anonymous 2001). Hot-press wheat tortillas, compared to die-cut or hand-stretched products, are smoother in surface texture, more elastic, slightly chewy, and resistant to tearing and cracking (SernaSaldivar et al 1988; Bello et al 1991; Friend et al 1993), making hot-press tortillas suitable to be used as the "wrap", "envelope" or "folder" for a countless array of fillings (Tortilla Industry Association, www.tortilla-info.com). Basic ingredients for wheat tortillas are wheat flour, water, salt, and shortening or oil; other ingredients such as leavening agents, prescrvatives, dough conditioners, cmulsifiers, and flavorings may also be used.

Bello et al (1991) developed a practical laboratory procedure for preparing and evaluating hot-press wheat tortillas. Friend et al (1993) investigated the effects of hydrocolloids on processing and qualities of wheat tortillas and found that the addition of natural or modified gums $(0.3-0.5 \%)$ could improve the product's shelf life and freezethaw stability. They also indicated that tortillas containing higher levels $(0.5-1.0 \%)$ of gums tended to have more undesirable translucent areas and less whiteness; proper gluten development appeared to be essential for good dough machinability, tortilla qualities, and tortilla shelf stability. Added wheat gluten significantly enhanced tortilla rollability, whereas other protcin sources decreased storage stability (Suhendro et al 1993).

\footnotetext{
'A joint contribution of the University of Nebraska $\Lambda$ griculture Research Division and the United States Department of A griculture, Agriculture Research Service as Journal Series Paper No. 13783. Mention of firm names or trade products does not imply that they are endorsed or recommended by the University of Nebraska or USDA over other firms or products not mentioned.

${ }^{2}$ Postdoctoral research associate and professor, respectivcly, Department of Food Science and Technology, University of Nebraska, Lincoln, NE 68583-0919.

${ }^{3}$ Corresponding author. E-mail: djackson $1 @$ unl.cdu. Fax: 402-472-I693.

${ }^{4}$ USDA-ARS, 362C Plant Science Hall, University of Nebraska, Lincoln, NE 68583-0915.

${ }^{5}$ Professor, Department of Biometry, University of Nebraska, Lincoln, NE 685830712 .
}

Publication no. C-2003-0615-04R

This article is in the public domain and not copyrightable. It may be freely reprinted with customary crediting of the source. American Association of Cereal Chemists, Inc., 2003.
Wheat flour is the primary tortilla ingredient and accounts for $80-95 \%$ of the dry matter in tortillas (Waniska 1999). Thus, flour characteristics primarily determine wheat tortilla qualities. Typical commercial tortilla flours are milled from hard red winter wheats with moderate to strong dough strength; the protein content ranges from 9.5 to $11.5 \%$ for hot-press tortillas or from 10.0 to $14.0 \%$ for other products (Serna-Saldivar et al 1988; Waniska 1999). McDonough et al (1996) found that the texture of tortillas depended on the retention of steam and leavening gases by the gluten matrix. Wang and Flores (1999a) studied the impact of wheat classes and flour milling streams on tortilla texture propertics. Their results indicated that both flour protein content and farinograph water absorption were positivcly correlated to tortilla foldability, and solt wheat flours were not suitable for tortilla products. In another study, they found that both wheat starch and gluten had significant effects on tortilla rupture distance; starches from different wheat classes affected foldability of tortillas (Wang and Flores 1999b). Because the fractionation and reconstitution method was used for their study, certain water-soluble components were not included in the tortilla formula, and the natural bonds between protein and starch granules were thus different in those systems. The reconstitution method was not suitable for the study of a high-fat (shortening) tortilla system (Wang and Flores 1999b). Wang and Flores (2000) also observed that flour protein content, particle sizc, and protein quality (high molecular weight protcins and low molecular weight proteins) affected tortilla texture; the particle size was the primary contributor to tortilla extensibility and rollability. Mao and Flores (2001) found that damaged starch affected tortilla's stretchability, firmness, and rollability.

Wheat starch, as the most abundant component in wheat flour, is composed of amylose and amylopectin. Lower amylose (partial waxy) or amylose-frec (waxy) wheat flours have unique flourstarch pasting properties (Graybosch et al $200(0)$ ), and the amylose content has a significant impact on Asian salted noodle products (Seib 2000). Lee et al (2001) found that low flour amylose content was associated with high gas formation during fermentation, whilc the gas retention coefficient decreased. Bread products prepared using lower amylose flours had larger volumes, more porous crumb structure, and higher moisture contents after seven days of storage at $4^{\circ} \mathrm{C}$ (Lee et al 2001 ).

With the availability of waxy wheat, it is possible to manipulate flour amylose content without dilution of wheal gluten (Graybosch 1998; Graybosch et al 1998). Up to now, there has been only one report of the impact of amylose content on wheal tortilla processing and product quality (Waniska et al $20(2)$ ), and partial waxy wheats with slightly (1.0-3.3\%) lower amylose content were used 
TABLE I

Hot-Press Wheat Flour Tortilla Formulation

\begin{tabular}{lcc}
\hline Ingredient & Amount (g) & $\%$ Flour Basis \\
\hline Flour (14\% moisture basis) & 1,000 & 100 \\
Salt & 17 & 1.7 \\
SSL: & 3 & 0.3 \\
Potassium Sorbate & 6 & 0.6 \\
Baking powder (Calumet, double acting) & 8 & 0.8 \\
Fumaric acid & 2 & 0.2 \\
Vegetable shortening (Crisco) & 80 & 8 \\
Water $\left(35^{\circ} \mathrm{C}\right.$ ) & adjusted & adjusted \\
\hline
\end{tabular}

Sodium 2 stearoyl lactylate.

bontains baking soda, cornstarch, sodium aluminum sulfate, calcium süffate, and nónocalcium phosphate.

Needs further grinding before use.

Amount of water calculated for wild type and waxy flour ratios of flour blend and farinograph water absorption (FWA) values.

in that study. The objectives of the current study were to determine the characteristics of flour blends with various amylose contents $(<1 \%-29 \%)$, to evaluate the effects of amylose content on wheat tortilla quality, and to investigate the application of waxy wheat in wheat flour blends for tortillas.

\section{MATERIALS AND METHODS}

\section{Wheat Samples}

One hard white wheat, 'Nuplains' $(\mathrm{N})$, and one hard red wheat, 'Centura' (C), were sclected for this study. Both cultivars are wildtype wheats that were planted in Clay Center, NE, during 2000. A waxy what sample obtained from a composite of waxy wheat experimental lines planted in Yuma, AZ, in 2000, was used to manipulate wheat flour amylose content.

\section{Wheat Milling}

All three wheat samples used in the study were milled into straight-grade flours using a Buhler laboratory mill according to Approved Method 26-21 A (AACC 2000). The flour yields ranged from 66.1 to $71.5 \%$.

\section{Wheat Flour Blends}

The waxy flour was blended with each of the two wild-type flours ( $\mathrm{N}$ and $\mathrm{C}$ ) using scven blending ratios. There wcre a total of $14(2 \times 7)$ flour blends. The percentage waxy flour in blends was 0 , $10,20,30,40,50$, and $100 \%$, respectively. A commercial tortilla flour (Buccanccr) (ConAgra Grain Processing Companies, Omaha, $\mathrm{NE}$ ) was used as a reference flour.

\section{Flour Characteristics}

Flour protein content $(\% \mathrm{~N} \times 5.7)$, falling number $(\mathrm{FN})$, pasting properties using the Rapid Visco Analyser (RVA) (Ncwport Scicntific, Warricwood, NSW, Australia), dough mixograph characteristics, and dough farinograms wcre determined according to Approved Mcthods 46-30, 56-81B, 76-21, 54-40A, and 54-21, respectively (AACC 2000).

Flour SDS sedimentation volume was mcasured using modifications of Approved Mcthods 56-61 A and 56-70 (AACC 2000). Both SDS and bromphenol bluc regents were used; $2.0 \mathrm{~g}$ of flour at a $14 \%$ moisture basis was used.

Total starch content was measured by Servi-Tech Laboratories (Hastings, NE), and damaged starch content was tested by Medallion Laboratorics (Minneapolis, MN). Flour color was measured using a chroma meter (CR-300, Minolta Camera Co., Ltd., Chuo-Ku, Osaka, Japan). Values determined were $L^{*}$ (brightness or whiteness), $a^{*}$ (redness and greenness), and $b^{*}$ (yellowness and blueness). Flour swclling volume and swelling power were determined using the method of Crosbie et al (1992).

Apparent amylose contents were determined using two methods. In the lirst procedure, flour was dispersed in dimethyl sulfoxide
(DMSO), and the modified colorimetric iodine $\left(\mathrm{I}_{2}\right)$ binding method of Knutson and Grove (1994) was followed. The second procedure used was a differential scanning calorimetry (DSC) method (Mestres et al 1996). Purified amylose from wheat starch was used to prepare a standard curve for the iodine $\left(\mathrm{I}_{2}\right)$ binding method, and blends of purificd wheat starch amylose and amylopectin were used to generate the calibration curve for the DSC method. Flour from 'Scout 66' wheat was used as a standard (defined amylose content) sample in both methods for further sample calibration.

\section{Tortilla Preparation}

Hot-press wheat tortillas werc preparcd with the formula shown in Table I. Water addition was calculated as

$$
\begin{aligned}
\text { Water }(\mathrm{mL}) & =(\% \text { wild } \times \% \mathrm{FA1} \times 86 \%+\% \text { waxy } \\
& \times \% \text { FWA } 2 \times 68 \%) \times 1,000
\end{aligned}
$$

where $\%$ wild and \%waxy were the percentages of wild flour and waxy flour in the flour blend, respectively; \%FWA1 and \%FWA2 were the determined farinograph water absorptions of wild-type flour and waxy flour, respectivcly.

Modified procedures of Bello et al (1991) were used for the dough preparation and tortilla baking. A Hobart mixer (model AS 200 DT, Hobart Corporation, Troy, $\mathrm{OH}$ ) was used for dough mixing: 1) dry matcrials were mixed $2 \mathrm{~min}$ at low speed (1st position) using the flat blade; 2) the shortening was then added and mixing continued another $6 \mathrm{~min} ; 3$ ) the mixer blade was changed to a hook type, and water was added and the dough mixed about $2 \mathrm{~min}$ at low speed until no dry flour could be seen; 4) the dough was then mixed at medium speed ( 2 nd position) $\approx 2-4$ min until a soft, cohesive, and pliable dough was properly developed. After mixing, the dough was covered with plastic film and rested for $5 \mathrm{~min}$ at room temperature $\left(21^{\circ} \mathrm{C}\right)$. The rested dough was manually presheeted then further mechanically pressed and divided into 36 dough pieces and rounded into small dough balls for $35 \mathrm{sec}$ using the Dutchess dough divider and rounder (model $100190 \mathrm{JN}-3$, Dutchess Baker's Machinery Co., Inc., Supcrior, WI). The dough balls were covered with plastic film and rested $10 \mathrm{~min}$ at room temperature $\left(21^{\circ} \mathrm{C}\right)$ before they were hot pressed and baked.

A pilot line including pressing platens, a three-ticr gas oven (model 0P01004-07 Micro Combo W/Head), and a five-tier cooling conveyor (model OCC1208-03) was used to prepare the tortillas (Lawrence Equipment, So. El Monte, $\mathrm{CA}$ ). Both top and bottom hot plate temperatures were set at $196^{\circ} \mathrm{C}$; press time was $0.8 \mathrm{sec}$ using a medium pressure setting (middle position). The oven tempcrature was set at $204^{\circ} \mathrm{C}$, and the oven dwell time was $40 \mathrm{sec}$. When the oven attained the designated temperature $\left(204^{\circ} \mathrm{C}\right)$, both the top and middle burners were turned off whilc the bottom burner was fully opened. Total tortilla cooling time at room temperature after baking and just before packaging was $20 \mathrm{~min}(2 \mathrm{~min}$ on the cooling conveyer and $18 \mathrm{~min}$ on a table with each tortilla individually separated). Tortillas at this time were defined as "fresh," and were used for fresh product characteristic analysis. Tortillas were stored in polyethylene bags at room temperature $\left(21^{\circ} \mathrm{C}\right)$ for 30 days. There were a maximum of 12 tortillas per bag, and the tortillas were individually separated using waxed papers to prevent them sticking together.

\section{Tortilla Dough Evaluation}

The dough mixing time, after adding water, and total dough weight were recorded. The pliability of tortilla dough was subjectivcly evaluated during its manual presheeting (after $5 \mathrm{~min}$ of rest). A pliable dough has a smooth appearance and is silky to the touch; it is soft but nonsticky and easily molded or spread (sheeted) but has elasticity (Bello et al 1991).

Three dough balls were weighed just after the dough dividing and rounding process; the average was recorded as the dough ball weight. Dough balls were subjectively cvaluated for shape, siz.c uniformity, smoothness, and stickiness after $10 \mathrm{~min}$ of resting. 
TABLE H

Means of Flour Characteristics ${ }^{a / b}$

\begin{tabular}{|c|c|c|c|c|c|c|c|c|c|c|c|}
\hline \multirow[b]{2}{*}{ Sample } & \multicolumn{3}{|c|}{ Farinograph } & \multicolumn{6}{|c|}{ Rapid Visco Analyser } & \multirow{2}{*}{$\begin{array}{l}\text { Total Starch } \\
(\%, \mathrm{db})\end{array}$} & \multirow[b]{2}{*}{ DSe $(\%)$} \\
\hline & WA & DT & ST & PT & PVT & PV & BD & SB & $\mathbf{F V}$ & & \\
\hline $\begin{array}{l}\text { CTFd } \\
\text { Centura } \\
\text { Nuplains } \\
\text { Waxy }\end{array}$ & $\begin{array}{l}62.0 \mathrm{~b} \\
59.5 \mathrm{c} \\
59.7 \mathrm{c} \\
79.5 \mathrm{a}\end{array}$ & $\begin{array}{l}2.1 \mathrm{c} \\
4.0 \mathrm{~b} \\
7.0 \mathrm{a} \\
5.0 \mathrm{~b}\end{array}$ & $\begin{array}{l}5.9 \mathrm{c} \\
52.5 \mathrm{a} \\
17.8 \mathrm{~b} \\
2.1 \mathrm{~d}\end{array}$ & $\begin{array}{l}68.6 \mathrm{a} \\
68.6 \mathrm{a} \\
68.6 \mathrm{a} \\
68.6 \mathrm{a}\end{array}$ & $\begin{array}{l}95.0 \mathrm{a} \\
95.0 \mathrm{a} \\
95.0 \mathrm{a} \\
82.2 \mathrm{~b}\end{array}$ & $\begin{array}{l}108 \mathrm{~d} \\
186 \mathrm{c} \\
219 \mathrm{a} \\
211 \mathrm{~b}\end{array}$ & $\begin{array}{l}72 \mathrm{c} \\
75 \mathrm{~b} \\
68 \mathrm{~d} \\
137 \mathrm{a}\end{array}$ & $\begin{array}{l}57 \mathrm{c} \\
110 \mathrm{~b} \\
132 \mathrm{a} \\
26 \mathrm{~d}\end{array}$ & $\begin{array}{l}94 d \\
221 b \\
283 a \\
101 c\end{array}$ & $\begin{array}{l}74.5 \mathrm{a} \\
75.8 \mathrm{a} \\
77.0 \mathrm{a} \\
77.0 \mathrm{a}\end{array}$ & $\begin{array}{c}8.6 \mathrm{~b} \\
6.6 \mathrm{c} \\
7.0 \mathrm{c} \\
10.4 \mathrm{a}\end{array}$ \\
\hline
\end{tabular}

Values followed by the same letter are not significantly different $(P<0.05)$.

b WÄ, water absoiption (\%), DT, dough development time (min), ST dough stability time (min); PT, pasting temperature $\left({ }^{\circ} \mathrm{C}\right)$, PVT;

peak viscosity temperature $\left({ }^{\circ} \mathrm{C}\right.$ ), $\mathrm{PV}$, peak viscosity (RVU), BD, breakdown (RVU); SB, setback (RVU); FV, final viscosity (RVU),

Damaged starch content (total starch basis).

Commercial tortilla flour:

TABLE II

Means of Flour Characteristies and Tortilla Qualities ${ }^{\mathrm{x}, \mathrm{b}}$

\begin{tabular}{|c|c|c|c|c|c|c|c|c|c|c|c|c|c|}
\hline \multicolumn{2}{|c|}{$\%$ Flour } & \multirow{2}{*}{$\begin{array}{c}\text { Protein } \\
(\%)\end{array}$} & \multirow{2}{*}{$\begin{array}{c}\text { Amylose } \\
(\%)\end{array}$} & \multirow{2}{*}{$\begin{array}{l}\text { SDSV } \\
\text { (mL) }\end{array}$} & \multirow[b]{2}{*}{ FN (sec) } & \multicolumn{3}{|c|}{ Mixographe } & \multicolumn{3}{|c|}{ 1-Day Color } & \multirow{2}{*}{$\begin{array}{c}\text { Opacity } \\
(\%)\end{array}$} & \multirow{2}{*}{$\begin{array}{c}\text { App. Puff } \\
(\%)\end{array}$} \\
\hline Wild & Waxy & & & & & WA & DT & TS & $\boldsymbol{L}^{*}$ & $a^{*}$ & $b^{*}$ & & \\
\hline CTP & 0 & $11.4 \mathrm{~b}$ & $27.7 b$ & $35.8 \mathrm{~b}$ & $326 d$ & 630 & $4.7 \mathrm{~b}$ & $4.0 \mathrm{~b}$ & $85.4 \mathrm{~b}$ & $-0.38 \mathrm{a}$ & $12.5 \mathrm{bc}$ & $90 \mathrm{a}$ & $93 \mathrm{a}$ \\
\hline $90^{\circ}$ & 10 & $13,0 \mathrm{a}$ & $264 \mathrm{e}$ & $412 a$ & $403 \mathrm{c}$ & 63.4 & $4.4 b$ & $4.0 \mathrm{~b}$ & $84.7 \mathrm{~b}$ & $-129 b$ & $12.9 \mathrm{~b}$ & $75 \mathrm{~b}$ & $86 \mathrm{~b}$ \\
\hline 80 & 20 & $13,0 \mathrm{a}$ & $23.7 \mathrm{~d}$ & $40.6 \mathrm{a}$ & 331 & 63.8 & $42 \mathrm{bc}$ & $3.0 \mathrm{c}$ & $83.7 \mathrm{bc}$ & $-1.26 b$ & $12.8 b$ & $66 \mathrm{~b}$ & $86 b$ \\
\hline 70 & 30 & $12.9 \mathrm{a}$ & $20.8 \mathrm{e}$ & $40,6 a$ & $264 \mathrm{e}$ & 64.2 & $4.1 \mathrm{bc}$ & $3,0 \mathrm{c}$ & $82.3 d$ & $-1.34 b c$ & $13.4 \mathrm{~b}$ & $57 \mathrm{bc}$ & $86 \mathrm{~b}$ \\
\hline$\theta$ & Waxy & $12.5 \mathrm{ab}$ & $0.8 \mathrm{~h}$ & $325 \mathrm{c}$ & $74 \mathrm{~g}$ & 670 & $2.0 \mathrm{~d}$ & $0.5 \mathrm{e}$ & $770 f$ & $-1,13 \mathrm{~b}$ & $14.8 \mathrm{a}$ & $22 \mathrm{e}$ & $80 \mathrm{bc}$ \\
\hline
\end{tabular}

- Values followed by the same letter in the same column are not significantly different $(P<0.05)$.

b When cultivar name of the wild type flour was not given, data were overall means of blends from both Centura and Nuplains with the same waxy flour ratios; Protein $(\% \mathrm{~N} \times 5.7), 14 \%$ moisture basis; Amylose content on a total starch basis; SDSV $=$ SDS sedimentation volume; FN $=$ falling number.

c WA $=$ water absomption (\%); DT = dough development time (min); TS = tolerance seore on a $0-7$ scale.

Tortilla apparent puffing, calculated one day after production,

\section{Tortilla Characterization}

Two raw tortillas, just after hot pressing and before baking, were used to measure raw tortilla diameter, which was the average of two diagonal measurements for each piece. The overall mean was recorded. The machinability during tortilla baking was subjectively rated. The possible reasons causing low baking machinability were descriptively recorded, such as sticking to the belt, early puffing leading to folding in the oven, etc.

The textural properties of fresh, 1-day, 3-day, 6-day, 9-day, 12day, and 15-day stored tortillas were determined using a texture analyzer (TA.XT2i, Texture Technologies Corp., Scarsdale, NY). The modified procedures of Flores-Farias et al (2000) were used to measure the tortilla tensile strength, rupture distance, and work required. Four $35-\times 70-\mathrm{mm}$ tortilla strips were tested for each sample using a TA- 96 probc with a testing speed of $1.0 \mathrm{~mm} / \mathrm{scc}$. Tortilla strip weights were recorded, and the adjusted tortilla tensile strength was calculated as

Adjusted tensile strength $(g)=($ tensile strength/strip weight $) \times 4.5$

One-day stored tortillas were used to determine $\mathrm{pH}$ values according to Approved Method 02-52 (AACC 2000). Ten 1-day stored tortillas were stacked and measured to determine the average tortilla thickness $(\mathrm{mm})$ and weight $(\mathrm{g})$ per picce. Baked tortilla diamelers (cm) were measured at two diagonals on each of 10 tortillas per sample and the overall mean was calculated. Tortilla opacity and apparent puffing (slightly raised tortilla surfaces) were subjectively estimated using their relative percent (\%) areas compared with the whole tortilla surface area; 1-day stored tortillas were used for these measurements. Puffing characteristics were also recorded during baking.

Tortillas after 1-day, 6-day, and 12-day storage were used for color testing (done in triplicate) using a chroma meter (model CR300, Minolta Camera Co., Ltd., Chuo-Ku, Osaka, Japan). Values for $L^{*}$ (brightness or whiteness), $a^{*}$ (redness and greenness), and $b^{*}$ (yellowness and blueness) were determined. Tortilla samples used for color measurement were used to determine moisture contents according to the two-stage Approved Method 44-15 (AACC 2000).

Six wooden dowels with different diameters were used to evaluate tortilla rolling characteristics. When the tortilla wrapped on a dowel cracked or broke, the sample days after baking and dowel diameter were recorded. Dowel diameters used in this research were $0.8,1.0,1.5,2.0,2.5$, and $3.0 \mathrm{~cm}$, respectively. The tortillas were tested for rollability every three days after baking for $3($ ) days. When rollability testing was conducted, flexibility was also measured. In this test, a piece of tortilla was put into a palm and then tightly gripped in a fist. Tortilla flexibility was subjectively rated on its stiffness and bending propertics. Any visual appearance of mold growth was also recorded during the 30-day storage period.

\section{Experimental Design and Statistical Methods}

The treatment factors were the two wild-type wheat cultivars and seven waxy flour blending ratios. The experimental design can be considered a split-plot design. The whole plots are the two wild-type flours, and the subplots are the seven flour blends. Because the initial data analysis (Proc Mixed Covtest option. Wald Z-tests) results of both our previous investigations and this study indicated that the experiment runs had no significant block elfects. the whole plot experimental design was a completely randomized design (CRD). There werc three replicates in this study. With this experimental design, both cultivar and blending ratio effects were tested simultaneously; higher testing accuracy was given to the blending ratios rather than the wheat cultivars.

The statistical analysis system (SAS Institute, Cary, NC), PCSAS software and procedures, were used for all statistical analyses. An analysis of variance (ANOVA) was performed using SAS Proc Mixed procedures for each tortilla characteristic. Mean comparisons among blending ratios were conducted using Duncan's multiple range test $(\alpha \leq 0.05)$. When there were no cultivar effects or 
cultivar-ratio interactions on tortilla quality responses, the covariate effects of protein content and dough charactcristics were analyzed. Correlation analysis between flour amylose content and tortilla quality parameters was also conducted.

\section{RESULTS AND DISCUSSION}

\section{Flour Blend Characteristics}

The results of flour blend characterization are shown in Tables II and III. For the commercial tortilla flour (CTF, Buccaneer) used in this study, both protein quantity $(11.4 \%)$ and quality (SDSsedimentation volume and dough strength) were lower than the wild-type flours. Also, the commercial tortilla flour contained malted barley flour, and had a lower falling number value (326) than the other two wild-type samples $(>470)$. The relative dough strength is shown with farinograms in Fig. 1. Because of the unusually high water absorption (79.5\%) of waxy flour, a lower fraction of the farinograph watcr absorption was used for waxy flour $(68 \%)$ to calculate the amount of water needed during tortilla processing than that used for wild-type flour (86\%). Statistical analysis results of the swelling properties of flour blends are shown in Fig. 2. As the result of malted barley flour addition, the commercial tortilla flour had a lower peak viscosity, set back, and final viscosity compared with the other two wild-type flours when analyzed by RVA (Table II, Fig. 3).

\section{Tortilla Dough Properties}

As expected, waxy blending ratios had significant effects $(P<$ 0.05 ) on both total dough weight and dough ball weight, while

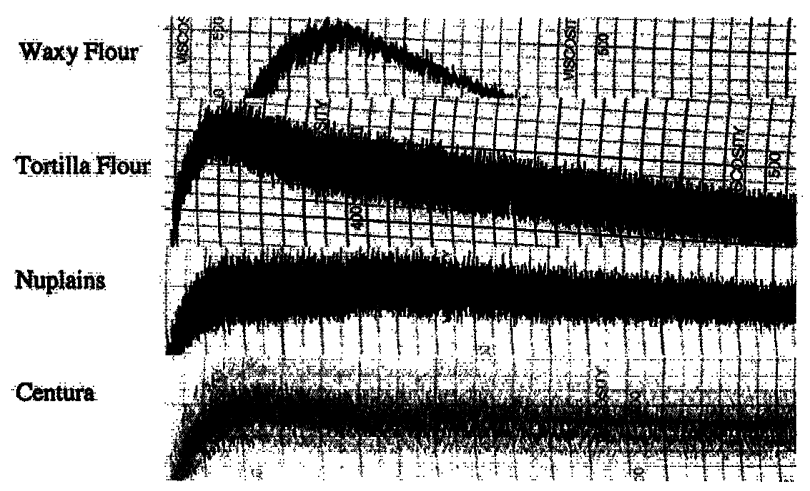

Fig. 1. Waxy and wild type flour farinograms:

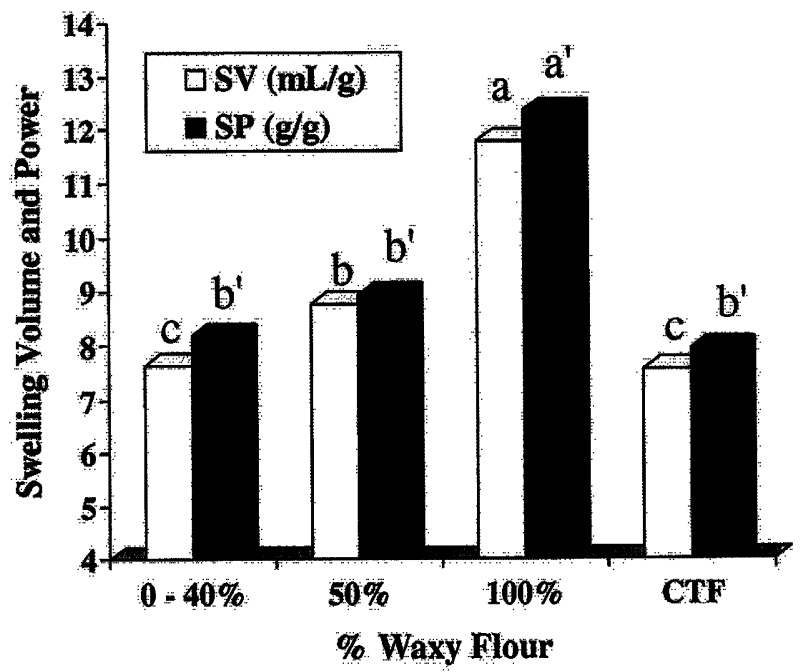

Fig. 2. Flour swelling volume (SV) and swelling power (SP). Commercial tortilla flour (CTF). Bars labeled with the same letter are not significantly different $(P<0.05)$. wheat cultivar did not affect these traits. This can be explained by the unusually high farinograph water absorption (79.5\%) of waxy flour; the two wild-type flours had equivalent water absorptions. With the addition of waxy flour, more water was added during tortilla processing (Eq. 1). The range of water addition used in this study was $51-54 \%$ based on a $14 \%$ moisture basis flour weight. Serna-Saldivar et al (1988) indicated that the optimal water addition used in commercial hot-press tortilla production was 48$52 \%$. Wang and Flores (1999b) found that optimum water addition was $15 \%$ less than the farinograph water absorption centered at $500 \mathrm{FU}$ according to the best performance of the dough. Bello et al (1991) used a farinograph dough peak centered at $750 \mathrm{FU}$ to determine the amount of water nceded, while Mao and Flores (2001) detcrmined water addition by farinograph absorption at $680 \mathrm{FU}$, which was $2.5 \%$ higher than the absorption resulting in 750 FU (Qarooni et al 1992). Differences between these were likely caused by differences in their processing systems.

Similarly, blending ratios greatly affected dough pliability, dough ball smoothness, and stickiness. Adding waxy flour into wild-type flours improved the tortilla dough ball smoothness and decreased stickiness; dough ball pliability was adversely affected by waxy flour addition. The waxy dough was relatively weak (Tables II, III). In addition to more water being used, tortilla doughs were weakencd by blending with waxy flour, and thus became smoother and less sticky. If the waxy flour was added at $>40 \%$, the dough lacked elasticity and was stiff; dough pliability was therefore rated low. The tortilla dough prepared using commercial tortilla flour was the most pliable, but it had the worst dough ball smoothness and stickiness characteristics. There were no significant differences $(P>0.05)$ in dough mixing time among all the flour blends. The round shaped and uniformly sized dough balls of all the tortillas indicated that the tortilla formulation and dough preparation procedures used in this study were appropriate.

For raw tortilla diameter, there was a slight interaction between wheat cultivar and waxy blending ratio $(P<0.05)$. The dough of Centura was stronger than any other samples used in this study (Tables II, III). Pure $(100 \%)$ waxy raw tortillas had significantly larger diameters $(17.7 \mathrm{~cm})(P<0.05)$ than any other raw tortillas prepared using Centura-Waxy blends (15.4-16.3). There were no other differences found at the $5 \%$ significance level.

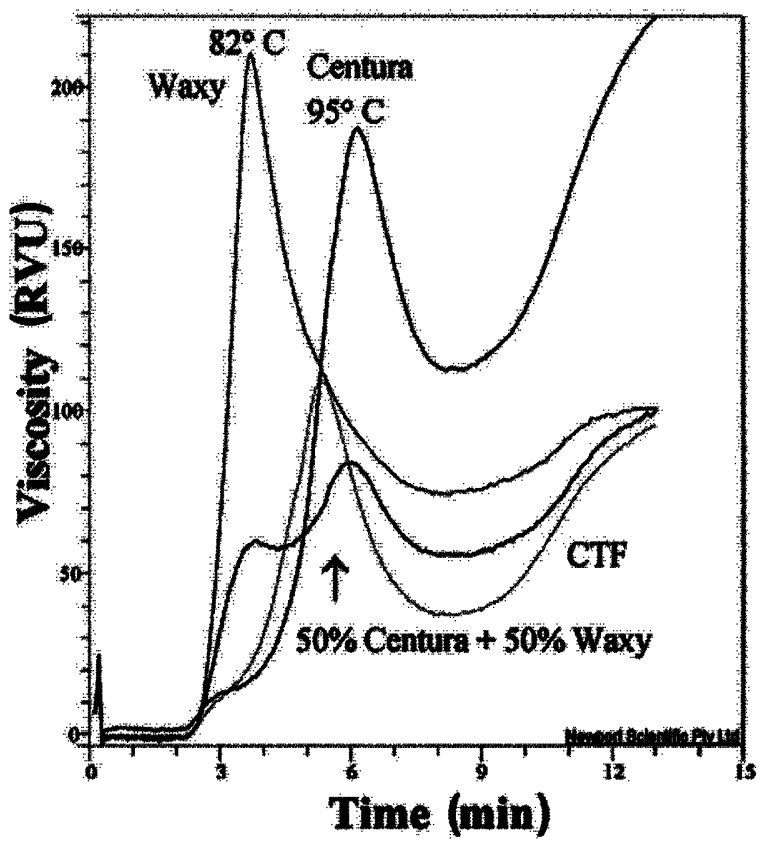

Fig. 3. Flour Rapid Visco Analyser (RVA) pasting curves. Temperatures shown are point of maximum peak viscosity. Commercial tortilla flour (CTF). 


\section{Tortilla pH Values, Color, and Moisture Contents}

The $\mathrm{pH}$ value range of tortillas prepared in our study was 5.085.20 ; the values were similar to those $(5.35 \pm 0.12)$ reported by Waniska et al (2002), but lower than other study reports (Friend et al 1993, 1995; Cepeda et al 2000). Lower tortilla pH values in this study were caused by the relatively low amount of baking powder $(0.8 \%)$ used in the tortilla formulations and the addition of fumaric acid $(0.2 \%)$ (Tablc I). This high acidity may delay the growth of microorganisms and thus prolong the tortilla shelf life. According to Waniska (1999) and Friend et al (1995), lowering the pH of tortilla dough might cause inferior dough machinability; however, tortilla dough handling problems were not a factor in this study.

All the parental flours had a relatively white color; the waxy flour $\left(94.2 \% L^{*}\right)$ was slightly brighter than Centura $\left(93.3 \% L^{*}\right)$ and Nuplains $\left(93.8 \% L^{*}\right)$. These differences were statistically significant $(P<0.05)$ but to human eyes all the dry flours looked similar. The sample of commercial tortilla flour had the lowest whiteness $\left(92.9 \% L^{*}\right)$. Interactions between blending ratio and tortilla storage time on tortilla color were significant $(P<0.05)$. Therefore, tortilla color data was analyzed within a specific storage day $(1,6$, or 12 days). For each of the three testing days, the whiteness (brightness, $L *$ ) value of baked tortillas was greatly decreased $(P<0.05)$ with an incrcase of waxy flour addition, while the redness $\left(a^{*}\right)$ and yellowness $\left(b^{*}\right)$ values were slightly increased (Table III). The tortillas prepared using 100\% waxy flour had significantly higher yellowness $(P<0.05)$, while there were no significant differences among other tortillas $(P>0.05)$. Tortilla whiteness $\left(L^{*}\right)$ is closely related to the opacity that is primarily caused by the diffraction of light from dispersed air bubbles (Waniska et al 2002). The initial flour color appears less critical to tortilla product color. The waxy flour used in this study had the whitest initial color and produced a relatively darker tortilla; the commercial tortilla flour, however, had the lowest initial brightness but gave a very white tortilla product (Table III). Retention of air bubbles in the dough and baked tortilla is considered the key to obtaining a white color and opaque appearance (Adams and Waniska 2002). Waniska et al (2002) speculated that addition of partial waxy wheat flour decreased tortilla whiteness by having a variable amylose-amylopectin dispcrsion or gel network formation during tortilla processing. Our results confirmed these observations. When discoloration was evaluated, only a slightly decrease of tortilla whiteness $\left(\Delta L^{*} 0-2 \%\right)$ during 12 days of storage was found. This minor discoloration may be primarily due to the bubbles losing air or collapsing, and tortilla texture variations such as starch staling during storage.

The moisture content range of prepared tortillas was $29.1-31.3 \%$. Tortillas made from $100 \%$ waxy flour had higher moisture contents than the wild-type flour tortillas one day after baking $(P<0.05)$; there were no significant differences found among tortilla products after 6 or 12 days of storage. Although the initial water addition was different for the flours and blends, the tortilla products had similar moisture contents. These results are similar to previous studies (Ranhotra 1985; Serna-Saldivar et al 1988; Bello et al 1991; Waniska et al 2002). Tortilla moisture loss during 12 days storage was $\approx 1 \%$. Similar results were found by Friend et al (1993).

\section{Tortilla Physical and Textural Characteristics}

Baked tortilla shape and production yield were subjectively characterized as the machinability during baking. Waxy blending ratios affected machinability but no cultivar effect was apparent (data not shown). When the portion of waxy flour in the blends was $>40 \%$, tortilla machinability during baking decreased. There were no commercially important differences in tortilla machinability among flour blends containing $0-30 \%$ waxy flour. The adverse effect of waxy flour addition on tortilla machinability was caused, in part, by early puffing in the oven. Compared with wildtype flours, waxy flour containing tortillas puffed much more on the top and middle oven tiers. This early puffing caused rolling or folding problems during tortilla baking and conveying, especially for the tortillas containing $>40 \%$ waxy flour. With the addition of waxy flour, more water was necessary to make the tortilla dough. Waxy starch has a lower gelatinization temperature and attains the peak pasting viscosity at a temperature $\approx 15^{\circ} \mathrm{C}$ lower than wildtype starch or flour (Hayakawa et al 1997; Otobe et al 1997; Graybosch et al 2000). All these factors resulted in carlier puffing of tortillas containing waxy flour because polymer mobility and steam generation are important to the puffing phenomenon.

Baked tortilla weight was $38.8-40.5 \mathrm{~g}$. There were no treatment cffects (wild-type wheat cultivar or waxy blending ratio) found in this study $(P>0.05)$. This result can be casily understood in that the same amounts of flour and all other ingredients, except water, were used, and baking resulted in tortillas with similar moisture contents. For baked tortilla diameters, as in raw tortilla diameters, significant interaction effects between wheat cultivar and waxy blending ratio existed $(P<0.05)$. The addition of waxy flour increased baked tortilla diameters substantially $(P<0.05)$ lor the Centura-Waxy blends (diameter range $15.7-17.3 \mathrm{~cm}$ ). However, no significant differences were found among Nuplains-Waxy blend tortillas $(P>0.05)$ (diameter range $16.9-17.4 \mathrm{~cm})$. Waxy blending ratios greatly affected baked tortilla thickness $(P<0.05)$; no wheat cultivar effects or interactions were found $(P>0.0 .5)$. Tortillas made from pure waxy flour had the largest dianeters (17.4 $\mathrm{cm})$ and were thinnest $(2.69 \mathrm{~mm})$. As it was likely that fewer air bubbles were retained in the waxy tortillas, this probably contributed to the thinner characteristics. The thickness of baked tortillas was $2.69-3.30 \mathrm{~mm}$. Similar results were found by Waniska ct al (2002) where partial waxy flour tortillas had decreased heights.

Results of tortilla opacity data analysis indicated that both wheat cultivar and blending ratio had significant effects on tortilla opacitics $(P<0.05)$; no interaction effect was found. Addition of waxy flour decreased tortilla opacity (Table III). Tortillas prepared using Nuplains were more opaque than the products made from Centura; tortillas made from the commercial tortilla flour had high $(90 \%)$ opacity. Small air bubbles dispersed in tortillas diffract light to give an opaque appearance-a very important quality attribute of hot-press wheat tortilla products (Friend et al 1993; Cepeda et al 2000; Waniska et al 2002). The ability of tortilla dough to retain air bubbles during and after baking primarily determines the opacity of baked tortillas (Adams and Waniska 20(2)). Tortillas prepared using flours of high protein content, strong gluten (long farinograph dough stability time), low amylose content (addition of waxy flour), and high water addition appeared to have low opacity values (Table III). All the tortillas prepared in this research were opaque immediately after baking; however, the tortillas containing higher proportions of waxy flour $(\geq 30 \%)$ lost the opacity and became more translucent quickly (several minutes after production). This data suggests that gas retention after baking seems to be more important, or at least as important, during baking. Waniska et al (2002) found that tortillas prepared using higher amylose flours were thicker and morc opaque regardless of variation in protein quality. They also indicated that amylose was probably involved in the retention of air bubbles by forming gels. Hoseney et al (1969) stated that water-soluble components of wheal flour contributed 10 gas production and gas retention during breadmaking. These water-solubles are important in tortilla production as well (Wang and Flores 1999b). The amylose-gel theory secms to explain primarily the tortilla opacity phenomenon but more research needs to be conducted.

Tortillas were completely puffed during baking for all the treatments used in our study. Tortillas made from wild-type flours primarily puffed on the middle and bottom oven tiers, while products containing waxy flours puffed earlicr. The puffing data shown in Table III is the "apparent" puffing of tortillas (raised surfaces) estimated one day after baking, an estimate of the pereent puffed area. In fact, the degrec of the transformation from opaque to translucent made apparent puffing dilferent from the oven 
puffing. For tortillas containing high proportions of waxy flour, apparent puffing values would be less than the degree of puffing during tortilla baking. Hence, this apparent puffing is a unique tortilla quality index; it can represent the ability to retain small air bubbles. The interaction between wheat cultivar and waxy blending ratio on tortilla apparent puffing was significant $(P<$ 0.05). Blending ratios greatly affected apparent puffing of the Nuplains-Waxy blend tortillas $(P<0.05)$; the addition of waxy flour to wild-type flour decreased percent of tortilla apparent puffing (Table III). Apparent puffing was not significantly different among Centura-Waxy blend tortillas $(P>0.05)$.

Compared with breads, wheat tortillas are high shortening products (8\%, Table I) and thus have better shelf stability. In this study, no breakage occured when tortillas were wrapped on the wooden dowels $(1.5-3.0 \mathrm{~cm}$ diameters) during the entire 30-day storing period. Only tortillas prepared using the commercial tortilla flour broke on 0.8 and $1.0 \mathrm{~cm}$ diameter dowels after more that 20 days storage (Table IV); compared with others, these tortillas had a good opaque appearance and were very soft but not strong enough to withstand rolling. The low flour protein content (Table III) was likely the cause of relatively low rollability. Earlicr studies similarly indicated that tortillas made from higher protcin content and quality (strength) flours had better rollability characteristics (Suhendro et al 1993; Dally and Navarro 1999; Wang and Flores 1999a, 2000; Waniska et al 2002). The rollability (brcakage time) of the commercial flour tortillas (six production replicates) in the study ranged between 21 and 27 days and the test did not differentiate between amylose treatment ratios (Table IV); this variation suggested that the rollability test was not extremely sensitive and also subject to inherent tortilla variability. However, the subjective tortilla flexibility test used in this rescarch appeared to be morc sensitive and was able to differentiate between treatments (data not shown). Correlation cocfficients $(r)$ between flexibility scores (days 3-9) and amylose contents were 0.78-0.81 $(n=48, P<$ $0.001)$; for days $12-30, r=0.86-0.94(n=48, P<0.001)$. Results suggested that waxy blending ratios exclusively influenced the tortilla flexibilitics on the 10 testing days (every three days after baking with a total of 30 days storage); no wheat cultivar or intcraction elfects werc found. The addition of waxy flour (higher blending ratio) decreased tortilla flexibility. This can be explained hy the poor small air bubble retention ability of waxy flour dough and paste or waxy starch staling characteristics (Torres et al 1994; Waniska 1999; Lec et al 2001; Waniska et al 2002). Wang and Flores (1999a) indicated that a high protein content and increased watcr addition during tortilla production resulted in larger air cells; large air cells would collapse after storage and thus increase tortilla firmness and lower the bending ability.

Visible mold growth during tortilla storage was recorded as the first day after baking on which mold colonies were visible (Table
IV). For each tortilla sample, there were nine bags of products (threc bags per replicate, total of threc replicates per sample); fewer than three bags had visible mold growth. There were no visible mold colonies on the tortillas prepared using a high $(\geq 50 \%)$ proportion of waxy flour blends, even though the parental flour (Centura) product had visible mold colonies formed during storage period (Table IV). This may be due to glass transition temperature $\left(T_{q}\right)$ differences between tortillas (shelf life is influenced by the temperature difference between $T_{\mathrm{g}}$ and storage temperature). These parameters were not measured in this study. Waxy wheat starch had higher transition temperature $\left(T_{\mathrm{o}}, T_{\mathrm{p}}\right.$, and $\left.T_{\mathrm{c}}\right)$ than wild-type wheat starch (Hayakawa et al 1997). The acidity (pH value) and moisture content levels were the same for all the samples. To fully understand this mechanism, additional studies should be conducted. When mold was observed, the bag of tortillas was not used for further testing.

Statistical analysis results showed that significant $(P<0.05)$ interactions between waxy blending ratio and tortilla storage days existed for all the tortilla tensilc properties: tensile strength (force) to break the tortilla strip, rupture distance, and the cnergy (work) needed. Therefore, treatment effects were analyzed using the data on a specific storage day, that is, the simple treatment effects were checked. For the tensile strength characteristics, effects $(P<0.05)$ of blending ratio were found for fresh tortillas, I-day stored products, and all other tortillas tested in the study. There was no cultivar and blending ratio interaction $(P>0.05)$; wheat cultivar affected $(P<0.05)$ only the 1 -day stored tortillas. When the rupture distance was tested, the interaction effects between cultivar and blending ratio were significant $(P<0.05)$ for all products except the 6-day stored tortillas. For the Centura-Waxy blends, blending ratios had an influence $(P<0.05)$ on tortilla rupture distances, cxcept for 1-day stored products. For Nuplains-Waxy blends, however, waxy blending ratios only affected $(P<0.05)$ rupture distances of the fresh and 1-day stored tortillas. With regard to the work (energy) needed to break tortilla strips, waxy blending ratios had an impact only on the fresh and 1-day stored tortillas $(\mathrm{P}<$ $0.05)$; wheat cultivars had an impact $(P<0.05)$ on all treatments, except for fresh and 9-day stored tortillas.

Tensile properties of fresh, 1-, 3-, and 15-day stored tortillas arc shown in Table IV. Day-1 and day-3 storage periods appeared to be critical storage landmarks. Textural differences between the fresh and 1-day stored tortillas (storage time and day effects) were large. One-day stored tortillas partially retained the quality characteristics associated with fresh products (treatment and cultivar and blending ratio effects) (Table IV). The tortilla tensile property trends among 3-day stored products (cultivar and blending ratio effects) in this study werc opposite those of the fresh or 1-day stored tortillas. During the cntire storage period, the products prepared using pure wild-type flours (Centura, Nuplains, and Buc-

TABLE IV

Means of Tortilla Tenslle Properties?

\begin{tabular}{|c|c|c|c|c|c|c|c|c|c|c|c|c|c|c|c|}
\hline \multicolumn{2}{|c|}{$\%$ Flour $^{b}$} & \multicolumn{3}{|c|}{$\theta$-Day Tensile } & \multicolumn{3}{|c|}{ 1-Day Tensile } & \multicolumn{3}{|c|}{ 3-Day Tensile } & \multicolumn{3}{|c|}{ 15-Day Tensile } & \multirow{2}{*}{$\begin{array}{l}\text { Rolld }^{\mathbf{d}} \\
\text { (day) }\end{array}$} & \multirow{2}{*}{$\begin{array}{l}\text { Mold }^{e} \\
\text { (day) }\end{array}$} \\
\hline Wild & Waxy & Force & DIS & Work & Force & DIS & Work & Force & DIS & Work & Force & DIS & Work & & \\
\hline CTF & 0 & $380 \mathrm{be}$ & $14.5 \mathrm{f}$ & $3,850 \mathrm{e}$ & $528 c$ & $6.6 c$ & $2971 \mathrm{c}$ & $590 \mathrm{f}$ & $4, \mathrm{te}$ & $2,014 \mathrm{c}$ & $725 \mathrm{~d}$ & $28 \mathrm{c}$ & $1,737 \mathrm{c}$ & $21-27$ & 24 \\
\hline Centura & 0 & $388 \mathrm{a}-\mathrm{c}$ & $26.6 \mathrm{e}$ & $8,168 d$ & $587 \mathrm{bc}$ & $10.6 \mathrm{~b}$ & $5,150 \mathrm{~b}$ & $689 \mathrm{ef}$ & $7.3 \mathrm{a}$ & & $776 \mathrm{~d}$ & 3a & & $>30$ & 24 \\
\hline 90 & 10 & $446 a$ & $28.7 \mathrm{de}$ & 9,7 & $649 \mathrm{ab}$ & $10.1 \mathrm{~b}$ & & & & & & & & & 24 \\
\hline 80 & 20 & $426 \mathrm{ab}$ & $32.5 c-e$ & $10,023 b-d$ & $661 \mathrm{ab}$ & $9.5 \mathrm{bc}$ & $5,395 b$ & $803 \mathrm{~cd}$ & $6.1 \mathrm{ab}$ & $4,202 a$ & $872 \mathrm{~cd}$ & $4.0 \mathrm{~b}$ & $3 a b$ & $>30$ & 21 \\
\hline 70 & 30 & $43 \mathrm{fab}$ & $35.0 \mathrm{~cd}$ & $11,553 \mathrm{bc}$ & $709 a$ & $9.7 \mathrm{bc}$ & $5,898 \mathrm{ab}$ & $902 b c$ & $5.6 \mathrm{bc}$ & $4,350 \mathrm{a}$ & $1,002 \mathrm{bc}$ & $4.0 \mathrm{~b}$ & $3,419 \mathrm{a}$ & $>30$ & 18 \\
\hline
\end{tabular}

Values followed by the same letter in the same column are not significantly different $(P<0.05)$.

$\checkmark$ When cultivar name of the wild type flour is not given, data are overall means of blends from both Centura and Nuptains with the same waxy flour blending ratios.

c. Tensile force to break the tortilla strip in grams; DIS = rupture distance $(\mathrm{mm})$; Work = energy needed for rupture $(\mathrm{gmm})$ :

d. Tortilla rollability expressed as the day after baking on which tortilla breakage occured when wrapped on a wooden dowel.

- Vistble mold during storage expressed using the first day on which the mold colonies were visible. 
caneer) needed less force to be broken during tensile testing than tortillas prepared with waxy flours, and there were no significant differences $(P>0.05)$ among these three wild-type flours. The lower force requirements, as well as good flexibilities mentioned previously, are due to the wild-type flour dough's good small airbubble retention and less firm texture (Wang and Flores 1999a; Waniska et al 2002). Quality differences among tortillas prepared using flour blends (cultivar and blending ratio effects) were similar during 3-15 day storage periods; only the magnitude of the response changed. For fresh tortillas, the addition of waxy flour decreased the tensile strength, and increased the rupture distance (Fig. 4). Similar results were found for 1-day stored tortillas although the force increased, the rupture distance and work needed dramatically decreased when compared with fresh products (Fig. 5). Waniska et al (2002) reported that partially waxy wheat flours created fresh tortillas requiring less rupture force, yet had a much longer rupture distance; the change of these characteristics during storage depended on the samples. The rupture work (cnergy) is the area under the tensile curve (force vs. distance); its magnitude can be thought of as being a balance between tensile strength and rupture distance. For the fresh and 1-day stored tortillas, adding more waxy flour increased rupture work and the work required for tortillas stored longer ( $\geq 3$ days) depended only on the wheat cultivars (Table IV). Without exception, the tortilla rupture distance decreased during storage but products prepared with Centura had less change in rupturc distance. The stronger dough characteristics (Tables I and II) of the Centura flour were associated with this phenomenon. Higher protein contents and stronger dough characteristics give tortillas longer shelf stability (stretchability, rollability, foldability). Reports from others have been similar (SernaSaldivar et al 1988; Friend et al 1995; Dally and Navarro 1999).

As opposed to fresh or 1-day stored tortillas, waxy blending ratios adversely affected tortilla shelf stabilities after $\geq 3$ days storage; higher waxy flour addition resulted in a higher tensile force and shorter rupture distance (Table IV, Fig. 6). Graybosch (2001) reportcd similar results for breadmaking. One day after baking, breads prepared using cither 25 or $50 \%$ waxy flour had significantly softer crumb than the loaves from the wild-type flour. The situation reversed at 4 and 7 days after baking, and the waxy blends had firmer crumb than the wild-type loaves (Graybosch 2001). This can be explained by food staling characteristics. Lack of or lower amylose content (adding waxy flour to wild-type flour) can retard starch retrogradation by delaying initial starch recrystallization (Pomeranz 1983; Lineback and Rasper 1988), and that is why adding waxy flour improves fresh and short-time (1day) stored tortilla stability. With time, tortilla staling is influenced by amylopectin; more waxy flour increases starch retrogradation as more of the total starch recrystalizes over time. This suggests that the tortilla staling mechanism is similar to that of bread. Lee and colleagues (2001) found higher retrogradation enthalpy values in breads containing waxy wheat starch compared with breads containing regular wheat starch, while Bhattacharya et al (2002) reported that breads with $20-30 \%$ added waxy durum wheat flour decreased enthalpies and improved bread shelf life. Further studies in this field are required.

The weight of tortilla strips used for the tensile property testing was $3.32-5.28 \mathrm{~g}$. Rupture forces were linearly adjusted (Eq. 2). Data analysis results indicated no advantage from this adjustment. Similar results were obtained using the raw tensile forces and the adjusted forces. The inefficiency of the adjustment may be due to the nonlinear relationship between tortilla strip weight and tensilc strength. The dimensional or density differences among tortillas are important product quality characteristics that contribute to eating qualities.

\section{Covariate Effects: Protein Quantity and Quality}

In this study, wheat flour blends werc used to make the tortillas. Fractionation and reconstitution treatment methods were not used to achieve different amylose contents. This system would be the same as that used in food or flour milling industrics. With an increase in percent waxy flour, amylose content of a flour blends could be decreased. Amylose contents for Centura (29.1\%) and Nuplains $(28.6 \%)$ were not significantly different at the 5\%: level. Different blending ratios represented the variation of amylose content. When the blending ratio was changed, other flour quality characteristics such as protein content and dough strength were also altered. A crucial question was whether effects of blending ratio on tortilla qualities were caused by the variation in amylose content or by other (nonstarch) factors.

Given the cxperimental design used in this study, nonstarch factors can be treated as covariates of the blending ratio and their effects tested when neither the significant cultivar cffect or cultivar-

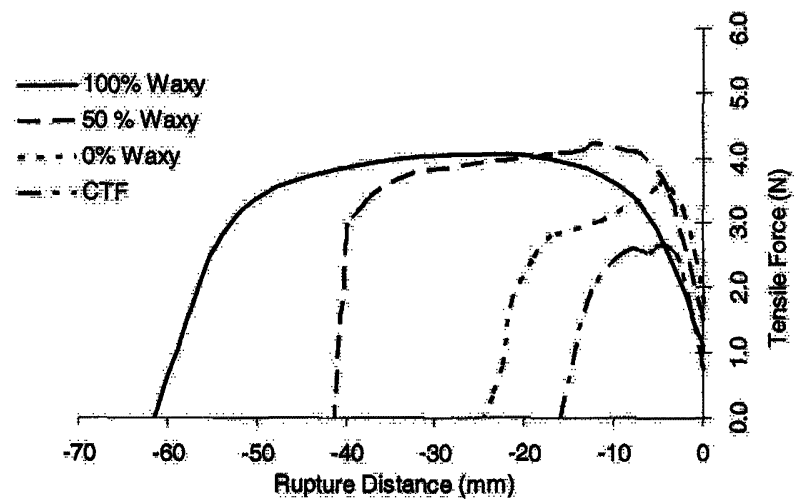

Fig. 4. Effects of waxy ratio on fresh tortilla tensile properties, Commercial tortilla flour (CTF).

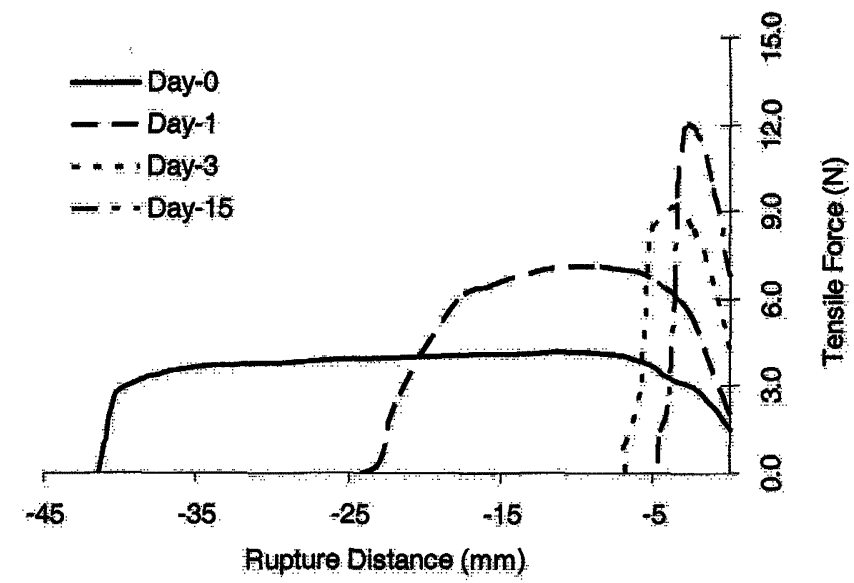

Fig. 5. Effects of storage time on tortilla tensile properties (50\% waxy + $50 \%$ Centura).

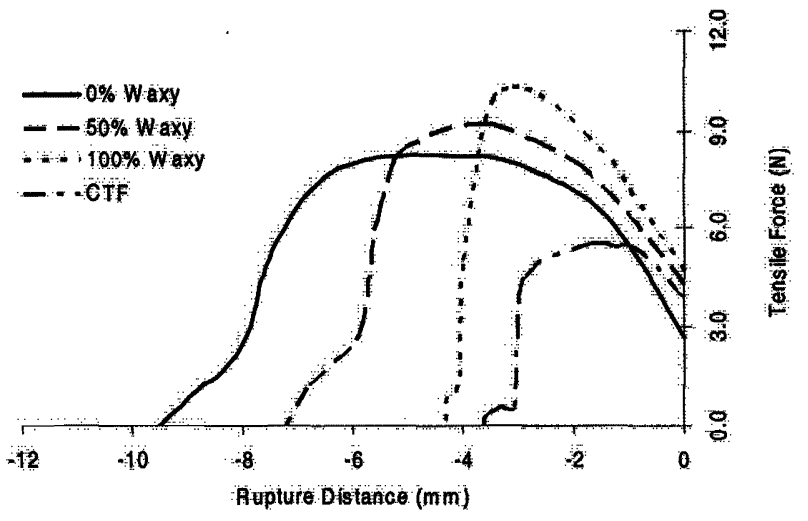

Fig. 6. Effects of waxy ratio on tensile properties of a tortilla stored three days Commercial tortilla flour (CTF); Centura as the wild type flour. 
ratio interaction exist $(P>0.05)$. Six parameters, protein content, mixograph dough development time, mixograph mixing tolerance score, flour SDS-sedimentation volume, and flour swelling volume and power, were selected as covariates of the waxy flour blending ratio. Covariate effects were tested for tortilla quality characteristics; 32 (22 tortilla textural indices, 4 color measures, 3 dough properties, 2 tortilla physical characters, and 1 production characteristic) tortilla quality parameters were tested on the six covariates; the total number of covariate effects was $192(32 \times 6)$. Only threc of 192 covariate effects were significant $(P<0.05)$; two of the threc significant effects were the mixograph dough tolerance score and the flour swelling volume effects on $b *$ values of 6-day stored tortillas, and one was the effect of flour swelling volume on tensilc strength of 12-day stored tortilla. The cffects of wheat cultivar or cultivar-ratio interaction were significant $(P<0.05)$ on tortilla rupture distances of all the tortilla products in the study. The testing of covariate effects, thercfore, could not be conducted on tortilla rupture distances.

Bccause vcry few significant covariate effects wcre found in this research, we can assume that the effects of blending ratio on tortilla qualities measured in the study were affected primarily by flour amylose content. The absence of covariate effects for both protein quantity and quality in the food system (flour) used is a very desirable design for the functional studies of starch components. Systems with altered amylose contents are difficult to create without resorting to fractionation and reconstitution procedures that tend to alter food (chemical) components. The availability of waxy wheat llour makes these studics possible and the conclusions drawn from this system should be more useful than those from fractionation and reconstitution studies.

\section{Amylose Impact}

Pearson correlations between amylose content and other flour or tortilla characteristics measured in this rescarch wcre analyzed. The results are shown in Tables V-VII. No significant (at 5\% level) relationships between flour amylose content and protein quantity (protcin content) or quality (SDS-sedimentation volume) were found (Table V). Dough mixograph propertics, dough development time, and tolerance score were highly correlated to flour amylose content. The doughs of low amylose flour blends

TABLE V

Correlation Coefficients Among Flour Characteristics and Tortilla Raw Diameter $(n=48)$

\begin{tabular}{|c|c|c|c|c|c|c|c|c|c|}
\hline Index" & PRO & SISSV & DT & TS & FSP & FSV & DMT & DBW & R'TD \\
\hline $\mathrm{AM}$ & $n s^{h}$ & ns & $0.88 * * \cdots$ & $0.89 * * * *$ & $-0.86 * * *$ & $-0.84 * * *$ & $-0.31 *$ & $-0.41^{* * *}$ & $-0.35^{*}$ \\
\hline PRO & & 0.9()$^{* k * *}$ & ns & $\mathrm{ns}$ & ns & ns & ns & $-(0.38 * *$ & $-\left(0.66^{* * * * *}\right.$ \\
\hline SDSV & & & $\mathrm{ns}$ & $0.34^{*}$ & $-0.48 * * *$ & $-0.50^{* * * *}$ & ns & $-(0.49: *$ & $-0.61 * * *$ \\
\hline TS & & & & & $-(0.79 * * * *$ & $-0.80 * * *$ & ns & $-\left(0.37^{* * *}\right.$ & $-0.51 * * *$ \\
\hline FSP & & & & & & $0.98 * * *:$ & ns & $0.37 * *$ & $0.46^{*} * *$ \\
\hline FSV & & & & & & & ns & $0.37 * *$ & $0.47 * * *$ \\
\hline
\end{tabular}

"AM = amylose content; PRO = protein content; SDSV = SDS sedimentation volume: $\mathrm{DT}=$ mixograph dough development time; TS $=$ mixograph tolerance score; FSP = flour swelling power; FSV = flour swelling volume; DMT = dough mixing time during tortilla dough preparation: DBW = dough ball weight: RTD = raw tortilla diameter (just after hot-pressing).

b Not significant at $\alpha \leq 0.05$.

$c *, * *, * * *=$ significantly different at 5,1 , and $0.1 \%$ level, respectively.

TABIE VI

Correlation Coefficients Between Flour Characteristics and Tortilla Physical Characteristics $(n=48)$

\begin{tabular}{|c|c|c|c|c|c|}
\hline Index ${ }^{a}$ & $L^{*}$ & DIA & THICK & OPA & PUFF \\
\hline $\mathrm{AM}$ & $0.92 * * * ; 1)$ & $n s^{c}$ & $0.51 * * *$ & $0.88 * 4$ & $0.57 * * * *$ \\
\hline PRO & IIs & $-0.70^{*: * *}$ & $\mathrm{~ns}$ & $\mathrm{~ns}$ & $-0.47 * * *$ \\
\hline SDSV & $0.45 *$ & $-0.50^{* * * *}$ & $0.36 *$ & $(0.29::$ & $\mathrm{ns}$ \\
\hline TS & $\left(0.82^{* * * * *}\right.$ & $-(0.49: * k:$ & $0.59 * *$ & $(0.80: * 1:$ & $0.46 * * *$ \\
\hline FSP & $-\left(0.73^{* * * *}\right.$ & $0.33^{* *}$ & $-(0.51 * * *$ & $-(0.66$ & $-0.43^{* * *}$ \\
\hline FSV & $-(0.74 * * * ;$ & $0.36^{*}$ & $-0.49^{* * * *}$ & $-0.69 * * *$ & $-0.43^{* *}$ \\
\hline
\end{tabular}

" $\mathrm{AM}=$ amylose content; $\mathrm{PRO}=$ protein content: SDSV $=$ SDS sedimentation volume; $\mathrm{D} T=$ mixograph dough development time: $\mathrm{TS}=$ mixograph tolerance score; FSP = flour swelling power; FSV = flour swelling volume: $L^{*}=$ whiteness of $\mathrm{I}$-day stored tortillas; DIA = baked tortilla diameter; THICK = thickness; $\mathrm{OPA}=$ tortilla opacity; $\mathrm{PUFF}=$ apparent puffing estimated 1-day after production.

$\mathrm{h} * * * * * * *=$ significantly different at 5,1 , and $0.1 \%$ level, respectively.

' Not significant at $\alpha \leq 0.05$.

TABLE VII

Correlation Coefficients between Flour Characteristics and Tortilla Tensile Properties $(n=48)$

\begin{tabular}{|c|c|c|c|c|c|c|c|c|c|}
\hline Index" & Fo & DO & Wo & $\mathbf{F 1}$ & D1 & W1 & F3-15 & D3-15 & W3-15 \\
\hline AM & $n s^{b}$ & $-(0.77$ *:*:ke & $-(0.76: * *$ & $\mathrm{ns}$ & $-0.66^{* * * *}$ & $-\left(0.63^{* * * *}\right.$ & $-\left(0.76^{* * * *} \sim-(0.81 * * *\right.$ & $\mathrm{ns} \sim(0.34 *$ & $\mathrm{ns} \sim-\left(0.38^{* * *}\right.$ \\
\hline PRO & $0.32 *$ & $0.3 .3 *$ & $0.34 *$ & $0.58 * * *$ & $0.34 \%$ & $0.52 * * *$ & ns & $0.67 * * 0.85 * *$ & $0.52 * * * \sim 0.77 * * *$ \\
\hline SDSV & (0.31* & $\mathrm{ns}$ & ns & $0.48 * * * *$ & $\mathrm{~ns}$ & $n s$ & $\mathrm{~ns} \sim-(0.31 *$ & $(0.51 * * * ; 0.63 * * * ;$ & $\mathrm{ns} \sim 0.41^{* *}$ \\
\hline DT & ns & $-0.69 * *: \leqslant$ & $-0.65 * * *$ & $\mathrm{~ns}$ & $-0.46 * * *$ & $-0.39^{* * *}$ & $-0.68^{* * * *} \sim-0.73^{* * * *}$ & $0.36 * \sim 0.54 * ; *$ & ns \\
\hline TS & $\mathrm{ns}$ & $-0.69 * * * *$ & $-0.68 * * \%$ & ns & $-0.51 * * *$ & $-0.47 * *$ & $-(0.74 * x ;-0.77 * x ;$ & $\mathrm{ns} \sim(0.50): \leqslant *$ & $n s$ \\
\hline FSP & ns & $0.60 *: * *$ & $0.59 * * *$ & ns & $0.63 * * * *$ & $0.43 * *$ & $0.52 * * * \sim 0.65 * * *$ & $\mathrm{~ns} \sim-0.38^{* *}$ & $\mathrm{~ns}$ \\
\hline FSV & $\mathrm{ns}$ & $0.58 * \cdots *$ & $0.58 * * *$ & ns & $0.61 * * * ;$ & $0.41 * *$ & $0.51 * * * \sim 0.65 * * *$ & $\mathrm{~ns} \sim-0.4 \mathrm{I}^{\mathrm{n} * *}$ & ns \\
\hline
\end{tabular}

"AM = amylose content; PRO = protein content; SDSV = SDS sedimentation volume; DT = mixograph dough development time: TS $=$ mixograph tolerance score; FSP = flour swelling power; FSV = flour swelling volume: F() = tensile strength of fresh (0)-day stored) tortillas; DO) = fresh tortilla rupture distance; W0 = work (energy) needed to break fresh tortilla strips: $\mathrm{FI}=$ tensile force of 1-day stored tortillas: $\mathrm{DI}=1$-day stored tortilla rupture distance: $\mathrm{WI}=$ work of $\mathrm{I}$ day stored tortillas; F3-15 = tensile forces of 3-15 days stored tortillas; D3-15 = rupture distances in the tensile testing on 3-15 days stored tortillas: W3-15 = work needed for breaking 3-15 days stored tortillas.

bot significant at $\alpha \leq 0.0 .5$.

: *.*:***: $=$ significantly different at 5,1 , and $0.1 \%$ level, respectively. 
needed shorter time to be formed and had low mixing tolcrances, bccause the dough of the waxy flour used in this study was very weak and more water was added during mixograph testing. The inverse effects of amylose content on flour swelling properties (Table V) can be explained by the waxy starch structure and the unique pasting and thermal properties. Waxy starch was gelatinized and attained peak pasting viscosity at much lower tempcratures than the wild-type samples. Other studies have indicated that the highly branched waxy starch structure, especially long branch-chains (DP $\geq 35$ ), contribute to cnhanced swelling properties (Sasaki and Matsuki 1998; Jane et al 1999). A close relationship between flour amylose content and falling number was also found in this study $(r=0.87, P<0.0001)$. Graybosch et al $(2000)$ similarly found that a low pasting peak temperature $\left(80^{\circ} \mathrm{C}\right)$ and high susceptibility to breakdown under conditions of high temperature $\left(95^{\circ} \mathrm{C}\right)$ and mechanical shear of a waxy flour paste cause low falling number values. A dough system is complex and interactions within and between flour constituents contribute to dough properties and final product qualities. Blends of both waxy and wild-type flours gave two RVA pasting peaks (Fig. 3); when the waxy ratio was low ( $\leq$ $30 \%$ ), the first (waxy) peak appeared only as a small shoulder.

The addition of water for tortilla dough preparation in this study was standardized (Eq. 1). More water was added when the waxy flour portion was increased; however, the number of tortilla dough balls per kilogram flour was fixed ( 36 dough balls). This explains the negative correlation between amylose content and dough ball weight. Dough ball smoothness and stickiness improved with addition of waxy flour to the blends, while dough pliability and tortilla production machinability during baking were adversely affected. Larger raw tortilla diameters were associated with lower flour amylose contents, but protein properties (both quantity and quality) seemed to have a more important effect on both raw tortilla and baked tortilla diameters (Tables V, VI). No close relationships were found between flour amylose content and baked tortilla diameters (Table VI). Baked tortilla thickness was solely affected by the flour amylose content in this study; lower amylose flours produced thinner tortillas (Table VI). No significant correlation was found between flour characteristics and baked tortilla weights; the average weight of a tortilla produced for this study was $39.9 \mathrm{~g}$ with a CV of $2.1 \%$. Compared with breads or noodle products, flour amylose contents are more important to tortilla whiteness; it has been suggested that low amylose flour dough has poor small air bubble retention during and after tortilla baking, and thus reduces tortilla opacity and lightness (Table VI) (Seib 2000; Lec et al 2001; Waniska et al 2002). The higher damaged starch content of waxy flour compared with wild-type flours is another possible rcason for low tortilla whiteness. However, there were no significant relationships found between flour amylose content (or any flour characteristic) and tortilla $a^{*}$ or $b^{*}$ color values. Very low flour amylose contents reduced tortilla opacity, early oven puffing, and low apparent puffing one day after production (Table VI).

As expected, flour amylose content greatly affected tortilla textural characteristics (Tables VI, VII). When tortillas were stored longer than three days at room temperature $\left(21^{\circ} \mathrm{C}\right)$, flexibility values were highly related to flour amylose content. The correlation analysis results between flour amylose content and tortilla tensile properties are shown in Table VII. No close relationship was found between amylose content and fresh or 1-day stored tortilla tensile strength (force); this relationship, however, became highly significant $(r=-0.8, P<0.0001)$ for tortillas $3-15$ days after production. Lower amylose contents seemed to contribute to the longer rupture distances of fresh or 1-day stored tortillas. However, this correlation became nonsignificant or had the opposite effect when tortillas were stored more than three days (Table VII). Waniska et al $(2002)$ also reported that lower amylose content modified the texture of tortillas on the first day. All these results are consistent with analysis of variance (ANOVA) for waxy flour blending ratio effects; the unique properties of the waxy flourstarch dough-paste system and tortilla staling characteristics contributed to these attributes. Flour amylose contents accounted for the variations in tortilla tensile strength (lack of covariate elfects); however, both amylose content and other factors (cultivar characteristics) were responsible for the rupture distances. To break the fresh or 1-day stored tortilla strips, more work (energy) was needed for products made with lower amylose flours because of their exccllent stretchability characteristics, but the significance of this relationship decreased when the tortillas were stored for a longer ( $\geq 3$ days) time. Tortilla tensile work was determined by both flour amylose content and other factors related to wheat cultivar. The correlations confirmed that somewhere within 1-3 days of storage time, a critical change in tortilla quality took place at room temperature $\left(21^{\circ} \mathrm{C}\right)$; slightly lower amylose content flours appeared to improve quality at $\leq 1$ day of storage but decreased quality after three days of storage.

\section{Optimal Amylose Contents}

Tortilla textural characters and shelf stabilities, except for the slight decrease in flexibility, were improved by adding waxy flour to wild-type flours (Tablc IV). Some tortilla dough and final product characteristics were improved by lowering flour anylose contents (adding waxy flour), while other attributes were degraded (Table III). To estimatc the optimum addition of waxy flour (or amylose content) for tortilla production, tortillas prepared from all the flour blends were compared with the tortilla product made from the commercial tortilla flour (Table III).

When $\leq 30 \%$ waxy flour was used, there were no substantial differences in dough pliability and tortilla machinability characteristics among the tortilla products made from commercial tortilla flour and waxy flour blends. For tortilla color (whiteness), 20\% waxy flour addition had no significant effect $(P>0.05)$ (Table III); tortilla flexibilities of products made with $20 \%$ waxy flour were acceptable. The most limiting factor was tortilla opacity, which significantly decreased $(P<0.05)$ when waxy flour was used (Table III). Cultivar effects on tortilla opacity were also) significant $(P<0.05)$. With the Centura-Waxy blends, there were no differences $(P>0.05)$ in tortilla opacity values among ()$-20 \%$ waxy blends; for the Nuplains-Waxy blends, there were no differences between 10 and $20 \%$ waxy blends, but these tortillas were less opaque than the products made from Nuplains. If the amount of waxy flour used did not exceed $20 \%$, tortilla opacity decreases caused by lowering amylose contents were acceptable. Therefore, the appropriate waxy flour addition level was $10-20 \%$ and the corresponding optimal amylose content was $24-26 \%$ (Table III).

\section{CONCLUSIONS}

Waxy flour and flour blends at different amylose content levels were characterized. The waxy flour sample showed unusually high (79\%) farinograph water absorption, cven though the waxy dough was weak. Flour blends with amylose contents between $<1$ and $29 \%$ were used to prepare wheat tortillas. The quantitative and qualitative parameters related to flour proteins (measured in this study) had a very limited impact on tortilla qualities, while the amylose content was closely related to tortilla dough propertics, tortilla machinability during baking, cooked tortilla (fresh and stored) physical or textural characteristics, and tortilla shelf stabilitics. Adding 10-20\% waxy flour conferred superior tortilla quality, and the optimal amylose content range appeared to be $24-26 \%$.

Fresh tortillas containing waxy flour had excellent stretchability. This characteristic might be ideal for restaurant (on-sitc) tortilla production or circumstances where tortillas are consumed shortly (within a day) after production. When thinner tortillas are preferred, lower amylose content (additions of waxy flour) flours are desirable for tortilla production. Waxy wheat flour allows for the easy creation 
of wheat-based food systems with different amylose-amylopectin levels for starch component functionality studies. Compared with the fractionation and reconstitution procedures used for over $\mathbf{5 0}$ years (Rho et al 1989), these waxy flour blending systems without significant covariate effects allow for the production and testing of foods that have fewer altered food components (Wang and Flores 1999b). The availability of waxy wheat flour makes these studies possible and the conclusions drawn from these systems should be more widely applicable than those from fractionation and reconstitution studies.

\section{ACKNOWLEDGMENTS}

We wish to thank Ralph D. Waniska for help in establishing our tortilla processing and product evaluation systems. Vern Hansen, Tianming Zhu, Yuli Xic, and Mary Shipman arc also acknowledged for substantial assistance with this project. Partial financial support was provided by the Nebraska Wheat Board.

\section{LITERATURE CITED}

Adams, J. L.., and Waniska, R. D. 2002. Effects of amount and solubility of leavening compounds on flour tortilla characteristics. Cereal Foods World 47:60-64.

American Association of Cereal Chemists. 2000. Approved Methods of the AACC, 10th ed. Methods 02-52, 26-21 A, 44-15, 46-30, 54-21, 5440A, 56-61 A, 56-70, 56-81B, and 76-21. The Association: St. Paul, MN.

Anonymous 200I. Tortilla sales continue to soar. Tortilla topics, the newsletter for the tortilla industry. July 16, 2001. CASA Herrera, Inc.: Pomona, CA.

Bello, A. B., Serna-Saldivar, S. O., Waniska, R. D., and Rooney, L. W. 1991. Methods to prepare and evaluate wheat tortillas. Cereal Foods World 36:315-322.

Bhattacharya, M., Erazo-Castrejon, S. V., Doehlert, D. C., and McMullen, M. S. 2002. Staling of bread as affected by waxy wheat flour blends. Cereal Chem. 79:178-182.

Ccpeda, M., Waniska, R. D., Rooncy, L. W., and Bcjosano, F. P. 2000. Effects of leavening acids and dough temperature in wheat flour tortillas. Cereal Chem. 77:489-494.

Crosbie, G. B., Lambe, W. J., Tsutsui, H., and Gilmour, R. F. 1992. Further cvaluation of the flour swelling volume test for identifying wheats potentially suitable for Japanese noodles. J. Cereal Sci. 15:271280.

Dally, V., and Navarro, I. 1999. Flour tortillas: A growing sector of the U.S. food industry. Cercal Foods World 44:457-459.

Flores-Harias, R., Martinez-Bustos, F., Salinas-Moreno, Y., Chang, Y. K., Hcrnande\%, J. G., and Rios, E. 2000. Physicochemical and rheological characteristics of commercial nixtamalised Mexican maize flours for tortillas. J. Sci. Food Agric. 80:657-664.

Friend, C. P., Ross, R. G., Waniska, R. D., and Rooncy, L. W. 1995. Effects of additives in wheat flour tortillas. Cercal Foods World 40:494-497.

Friend, C. P., Waniska, R. D., and Rooney, L. W. 1993. Effects of hydrocolloids on processing and quality of wheat tortillas. Cercal Chem. 70):252-256

Graybosch, R. A. 1998. Waxy wheats: Origin, properties, and prospects. Trends Food Sci. Technol. 9:135-142.

Graybosch, R. A. 2001. Null alleles at the waxy loci in wheat and oats: Origin, distribution and exploitation. Pages 164-169 in: Starch Advances in Structure and Function. T. I. Barsby, A. M. Donald, and P. J. Frazicr, cds. R. Soc. Chem.: Cambridge, UK.

Graybosch, R. A., Guo, G., and Shelton, D. R. 2000. Abcrrant falling numbers of waxy wheats independent of $\alpha$-amylase activity. Cereal Chem. 77:1-3.
Graybosch, R. A., Peterson, C. J., Hansen, L. E., Rahman, S., Hill, A., and Skerritt, J. H. 1998. Identification and characterization of U.S. wheats carrying null alleles at the $w x$ loci. Cercal Chem. 75:162-165.

Hayakawa, H., Tanaka, K., Nakamura, T., Endo, S., and Hoshino, T. 1997. Quality characteristics of waxy hexaploid wheat (Triticum aestivum L.): Properties of starch gelatinization and retrogradation. Cercal Chem. 74:576-580.

Hoseney, R. C., Finney, K. F., Shogren, M. D., and Pomeran«, Y. 1969. Functional (breadmaking) and biochemical properties of wheat flour components. II. Role of water solubles. Cereal Chem. 46:117-135.

Jane, J., Chen, Y. Y., Lee, L. F., McPherson, A. E., Wong, K. S., Radosavljevic, M., and Kasemsuwan, T. 1999. Effects of amylopectin branch chain length and amylose content on the gelatinization and pasting propertics of starch. Cereal Chem. 76:629-637.

Knutson, C. A., and Grove, M. J. 1994. Rapid method for estimation of amylose in maizc starches. Cercal Chem. 71:469-471.

Lee, M.-R., Swanson, B. G., and Baik, B.-K. 200I. Influence of amylose content on propertics of wheat starch and breadmaking quality of starch and gluten blends. Cercal Chem. 78:701-706.

Lineback, D. R., and Rasper, V. F. 1988. Wheat carbohydrates. Pages 277-372 in: Wheat Chemistry and Technology, Vol. I. Y. Pomeranz, ed. Am. Assoc. Cereal Chem.: St. Paul, MN.

Mao, Y., and Florcs, R. A. 2001. Mechanical starch damage clfects on wheat flour tortilla texturc. Cereal Chem. 78:286-293.

McDonough, C. M., Seetharaman, K., Waniska, R. D., and Rooney, L. W. 1996. Microstructure changes in wheat flour tortillas during baking. J. Food Sci. 61:995-999.

Mestres, C., Matencio, F., Pons, B., Yajid, M., and Flicdel, G. 1996. A rapid method for the determination of anylose content by using differential scanning calorimetry. Starch 48:2-6.

Otobe, K. C., Nagamine, T., Yanagisawa, T., Ohnishi, M., and Yamaguchi, I. 1997. Production of hexaploid wheats with waxy endosperm character. Cereal Chem. 74:72-74.

Pomeranz, Y. 1983. Molecular approach to breadmaking, an update and new perspectives. Baker's Dig. 57:72-86.

Qarooni, J., Ponte, J. G., Jr., and Posncr, E. S. 1992. Test baking procedure for evaluating flour tortilla quality. Assoc. Operative Millers Bull. (Dec.):6136-6138.

Ranhotra, G. S. 1985. Nutritional profile of corn and flour tortillas. Cereal Foods World 30:703-7()4.

Rho, K. L., Chung, O. K., and Seib, P. A. 1989). Noodles. VIII. The effect of wheat flour lipids, gluten, and several starches and surfactants on the quality of oriental dry noodles. Cercal Chem. 66:276-282.

Sasaki, T., and Matsuki, J. 1998. Effect of wheat starch structure on swelling power. Cereal Chem. 75:525-529.

Seib, P. A. 2000. Reduced-amylose wheats and Asian noodles. Cercal Foods World 45:504-512.

Serna-Saldivar, S. O., Rooney, L. W., and Waniska, R. D. 1988. Wheat flour tortilla production. Cercal Foods World 33:855-864.

Suhendro, E. L., Waniska, R. D., and Rooney, L. W. 1993. Effects of added proteins in wheat tortillas. Cercal Chem. 70:412-416.

Torres, P. I., Ramirez-Wong, B., Scrna-Saldivar, S. O., and Rooney, L. W. 1994. Effect of decorticated sorghum addition on the rheological properties of wheat tortilla dough. Ccreal Chem. 71:509-512.

Wang, L., and Flores, R. A. 1999a. Effect of different wheat classes and their flour milling streams on textural properties of flour tortillas. Cercal Chem. 76:496-502.

Wang, L., and Flores, R. A. 1999b. Effects of wheat starch and gluten on tortilla texture. Cercal Chem. 76:807-810.

Wang, L., and Flores, R. A. 2000). Effects of flour particle size on the textural propertics of flour tortillas. J. Cereal Sci. 31:263-272.

Waniska, R. D. 1999. Perspectives on flour tortillas. Cereal Foods World 44:471-473.

Waniska, R. D., Graybosch, R. A., and Adams, J. L. 2002. Effects of partial waxy wheat on processing and quality of wheat flour tortillas. Cereal Chem. 79:210-214. 